\title{
Journal on English as a Foreign Language
}

JEFL 2021, Vol. 11, No. 1, 21-41

Journal homepage: http://e-journal.iain-palangkaraya.ac.id/index.php/jefl

\section{Flipping the classroom to enhance EFL students' listening skill}

\section{Khoiriyah}

English Language Education Department, Faculty of Teacher Training and Education, Universitas Muhammadiyah Malang, Malang, Jawa Timur, Indonesia

Email: khoiriyah230693@umm.ac.id

Article history: Received: 12 May 2020

Available online: 5 February 2021

Accepted: 29 January 2021

Published regularly: March 2021

\begin{abstract}
Studies regarding the use of flipped instruction in language learning have been identified plentifully, little work has examined its use in teaching listening, particularly for specific language testing. In order to address this gap, the impact of the flipped classroom to enhance EFL students' listening skills, especially language testing, was examined. Furthermore, this study also explored the students' perspective toward their experience in having a flipped classroom. Accordingly, a mixed-method was employed by using pre-test and post-test after treatment, along with the online open-ended questionnaire. This study revealed that the average score of the post-test $(M=72.27)$ was significantly higher than the average score of the pre-test (64.06), indicating flipped instruction enhances the students' listening comprehension skills. Further, most of the students provoked positive feedbacks on their experience of having flipped classroom. This study might contribute as a guideline for EFL teachers to implement flipped instruction to increase the students' listening comprehension.
\end{abstract}

Keywords: flipped classroom; listening skills; students' listening skills; students' perspective

To cite this article: Khoiriyah. (2021). Flipping the classroom to enhance EFL students' listening skill. Journal on English as a Foreign Language, 11(1), 21-41. https://doi.org/10.23971/jefl.v11i1.2010

To link to this article: https://doi.org/10.23971ßjefl.v11i1.2010

Journal on English as a Foreign Language, 11(1), 21-41

p-ISSN 2088-1657; e-ISSN 2502-6615 


\section{Introduction}

As the basic receptive skill among the four language skills, listening is generally described as the ability to correctly interpret and understand the messages in the communication process. According to Emerick (2018), learners with a strong comprehension of listening skills are more able to participate effectively in class. It is necessary to obtain comprehensible input as needed to improve the language learning process. Unfortunately, most EFL students fail to cope with academic listening material. It might be due to the difficult nature of listening or it because the four language skills were the most overlooked and the least well taught in language class (Hamouda, 2013). There are some factors voiced by EFL learners with regard to their listening difficulties. Some of them are unfamiliar with the language, have less practice and less familiar with listening strategies, encounter difficulties in translating the language and have other psychological factors, such as anxiety and lack of concentration (Rintaningrum, 2018). Therefore, language teachers will make greater efforts to enhance their students' listening comprehension.

However, in a traditional language class, many scholars have indicated that students gain insufficient language input despite class time limitation resulting in ineffective teaching methods to facilitate the learning process. The rapid growth of technology advancement and the improvement of EFL teaching methods' theoretical developments have inspired new directions. Technology has reported bringing some easiness in learning English. It stimulates autodidact or self-taught learning and provides some enjoyments through songs, videos and other multimodalities recourses (Rintaningrum, 2016). In a classroom context, the use of ICT is basically beneficial to keep interaction between students and teachers, to keep the teaching materials and activities updated and lively, and also to provide students with a various of context. Consequently, technology enables students to improve their multitasking skills as well as their English skills (Rintaningrum, 2018). More specifically, Golonka et al. (2014) stated that technological advancement is beneficial for language learning such as increasing students' interest and learning motivation, providing ample access to target language (TL) input, increasing opportunities for interaction and collaborative learning, giving immediate corrective feedback, and providing teachers with an effective means to manage coursework and interact with multiple students. These benefits are basically promised by the implementation of the flipped classroom. 
The flipped classroom's notion is fundamentally depicted as the implementation of a classroom using blended learning where students are stimulated to learn content independently through an online platform in advance of class and used their time for discussion and problem-solving in inclass activities. Since it decreases the class time, it provides more opportunities to students for having one-on-one interaction (Maxson \& Szaniszlo, 2015). Thus, the teaching and learning focus moves from teacher-centred to learner-centred. The flipped classroom is often simply interpreted as the opposite of homework and direct lecture. Further, Computer-assisted language learning (CALL) literature may have only started to explore the implications of flipped language learning among language learners. Flipped classroom incorporates CALL literature which includes the use of technology to facilitate student's autonomy and control in the learning process (Köroğlu \& Çakır, 2017). A flipped classroom is strongly required to have two essential components: computerbased instruction for individual students as pre-class activities and collaborative community learning experiences inside the classroom as in-class activities (Shih \& Huang, 2019).

The theoretical basis of Vygotsky (1978) in language learning, Zone of Proximal Development (ZPD), tremendously supports flipped classroom approach. This theory represents the difference between the actual level of students' progress as it is driven by individual learning activities and their potential abilities being stimulated by guided problem-solving and/or collaboration with more competent peers (Lo \& Hew, 2017). Basically, flipped instruction requires learners to be responsible for their initial learning as a preclass activity. The student's current listening competence here is called their Zone of Actual Development (ZAD). Through interaction during class-time, learners can improve their understanding by moving ahead from their current ZAD into their ZPD (Kazemian et al., 2019). In other words, ZPD is a result of a learning process that reflects the difference between what learners can do on their own (ZAD) and what they can learn with other's help, either help from other learners or teachers in class (ZPD). In this stage, according to the scaffolding principle, as students begin to perform tasks in their ZADs independently, their ZPDs progress to the next level of their performance. Meanwhile, class time is used to link the differences between what was learned individually and the opportunity to execute activities that may require directed instruction or peer-work collaboration. The learning process happens effectively. In this way, student-centered learning emphasizes the essential role of social interaction in learning, resulting in significantly enhanced language skills (Rosell-Aguilar et al., 2018).

Journal on English as a Foreign Language, 11(1), 21-41

p-ISSN 2088-1657; e-ISSN 2502-6615 
Researchers have revealed the benefits and drawbacks of the flipped classroom in language learning. First, self-paced and self-managed learning is greatly facilitated as students can directly access the learning materials such as a pre-videotaped lecture or web-based materials outside of class (Ahmad, 2016; Tsai, 2019). Other research was conducted by Khonamri et al. (2020) reporting that e-based interactive flipped learning effectively improved the level of critical reading skills of Iranian EFL students. Flipped classroom provides greater flexibility and accessibility for students to design and take control over their own learning process than they can do in a traditional classroom design. Second, flipped classroom enhances the interaction of both the teacher-tostudent and student-to-student interactions since the pre-class and in-class activities are more active and engaging (Tecedor \& Perez, 2019). Third, an effective flipped classroom was successfully providing sufficient in-class activities to develop student thinking and group sharing (Love et al., 2014). Nonetheless, several problems were also encountered such as preparing the materials and designing the flipped classroom are always time-consuming (Lee \& Wallace, 2018). Other drawbacks are reported, including the students' low efficacy to use technology and some technical problems (Shih \& Huang, 2019). From those previous studies, the flipped classroom was implemented successfully in a higher education setting. Nonetheless, a further study is still deemed to conduct in a specific language learning skill.

With respect to the EFL context, Lee and Wallace (2018) implemented flipped instruction for Korean university students in a content subject using English as a foreign language. The students are required to complete a course evaluation and reflective learning logs. The study concluded that the students mostly viewed flipped learning positively although they encountered initial difficulties in adjusting to online platforms. The students appreciated it due to three foremost benefits; receiving immediate and sufficient feedback, providing ample opportunities to explore materials in-depth, and improving critical thinking on materials before in-class activities (Kim et al., 2017). Moreover, peer interactions were identified as a favourable advantage as well. In other research, Su Ping et al. (2019) investigated students' reflection toward their experience in a writing program with the structured flipped approach in Malaysia. This study concluded that most students had positive feedback since they expressed some flipped instruction benefits, including having more time to learn before class, increasing engagement and interaction among the students, providing more practices, improving motivation for in-class activities, and receiving immediate feedback in the in-class activity. Nonetheless, much of

Journal on English as a Foreign Language, 11(1), 21-41

p-ISSN 2088-1657; e-ISSN 2502-6615 
those researches were concerned only with exploring the students' motivation and perceptions.

Further, some quasi-experimental studies have been conducted in various EFL contexts. Flipped instruction, for instance, facilitated significant speaking skills development in term of speaking (Bezzazi, 2019), pronunciation, fluency and accuracy for the pre-service teachers (Köroğlu \& Çakır, 2017); and improved pronunciation of new vocabulary and vocabulary building for business students (Alnuhayt, 2018; El-Sawy, 2018; Kırmızıa, Özkan \& Kömeçb, 2019). Meanwhile, flipped classroom also facilitated to improve listening skill (Ahmad, 2016) and metacognitive strategies (Shih \& Huang, 2019).

Although numerous studies on flipped learning in various EFL settings are reported, few studies report empirical evidence investigating the impact on students' proficiency, especially listening skill. It is strongly supported by Turan and Akdag-Cimen (2019) in their current structured literature, explaining that most of the studies regarding flipped classroom are focused restrictedly only on speaking and writing skills. Based on the preceding explanations, mixed-method research on flipped classroom effect on students' listening skills was undertaken. Consequently, this research aims to investigate the effect of implementing flipped approach to improve the students' listening skills, and to explore the students' perspective regarding their experiences in having flipped classroom. The researcher considered that this study could contribute practically with regard to the implementation of flipped classrooms in listening skills, especially for enhancing the students' listening test proficiency as several considerations of its effectiveness will also be explored further in this study.

\section{Method}

\section{Research design}

This research employed a mixed-method investigating the flipped classroom's effect on students' listening skills and their perceptions toward their flipped learning experience. It combined quantitative and qualitative approaches for the broad purposes of a single study (Creswell, 2012). For the quantitative data collection, this research employed a one-group pretest-posttest design in which the same independent variable is measured in a group of participants before treatment is given (pre-test) and after the treatment (post-test) (Privitera \& Delzell, 2019). The independent variable of this research is the test result of students' listening comprehension. A group of EFL in Indonesia higher education were conveniently involved in this research. To know the impact of 
flipped classroom, students were asked to join pre-test on TOEFL-like listening comprehension and post-test after the treatment, using flipped classroom approach. They were given a treatment that covers four-week intensive flipped classroom focusing on listening part of TOEFL-like test. Then, the results of those tests were compared and analyzed. Meanwhile, qualitative data were gained from an online open-ended questionnaire to investigate the students' perceptions in experiencing the flipped classroom.

\section{Participants}

The participants were 51 students who joined a three-credit course, namely "Critical Listening", once a week for 16 meetings in a semester. The participants were taught by the author during the odd semester at English Language Education Department. They were second-year university students who have mostly already studied English for approximately eight years starting from high school level. Their English proficiency was considered to be at the intermediate and upper-intermediate level proven by the result of the initial English comprehension test. Further, the critical listening course primarily aims to advance students' listening skills, particularly everyday listening exercises in different contexts, and several listening tests such as TOEFL-like listening test, and several listening real test of TOEFL from Longman Preparation Course (Phillips, 2003).

\section{Data collection}

In pre-class, this preparation part consists of three main components: watching lecturing videos, studying TOEFL-like materials from websites, and joining an online TOEFL-like listening practice test. Students watched the lecture videos for the next lecture each week to learn the basic materials prior to class. Furthermore, they were also asked to have individual TOEFL-like training such as studying from the websites and having online exercises before class. Once the students were motivated to study the content at home, they were given an opportunity to review what they had learned in class. Then, they delivered some feedback on whether they missed any essential points. Further, there are three activities in the in-class activities, including TOEFL-like listening test simulation, giving feedback, and whole-class discussion. The researcher facilitated the students to check their understanding and provided some points for class discussion. Therefore, students were involved in the learning process by learning from each other. The procedures are shown in Figure 1.

Journal on English as a Foreign Language, 11(1), 21-41

p-ISSN 2088-1657; e-ISSN 2502-6615 


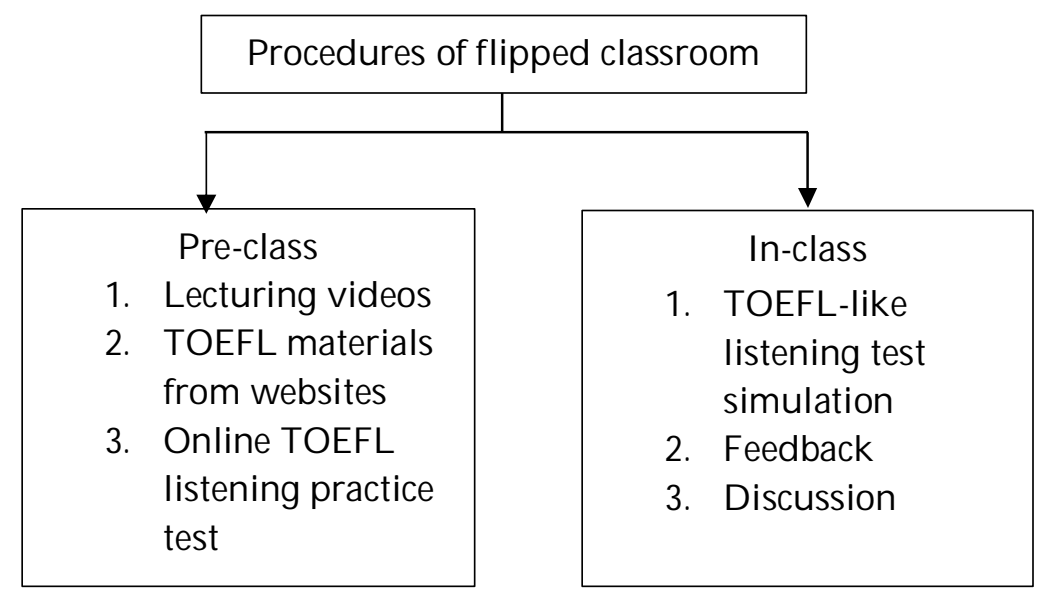

Figure 1. Pre-class and in-class activities for implementing flipped classroom

In order to meet the initial learning process, the listening materials from Longman Complete Course for the TOEFL Test (Phillips, 2003) were chosen as the main material. This book contains a variety of materials which together provide a comprehensive course of TOEFL-like preparation. Yet, the materials are also compiled from varied reliable websites (web-based materials) and videos from YouTube; then those are uploaded on google classroom. Meanwhile, the teaching materials of each week were summarized in Table 1.

Table 1. The materials taught during the flipped classroom

\begin{tabular}{|c|c|c|c|c|}
\hline No. & Week & Teaching materials & $\begin{array}{l}\text { Pre-class } \\
\text { activities }\end{array}$ & $\begin{array}{l}\text { In-class } \\
\text { activities }\end{array}$ \\
\hline 1. & 1 & $\begin{array}{l}\text { TOEFL listening part } 1 \text { - listening } \\
\text { to short talk(s) } \\
\text { - The strategies } \\
\text { - Who, what, where (WH- } \\
\text { questions) } \\
\text { - Draw a conclusion about } \\
\text { who, what and where } \\
\text { - Listen for who and what in } \\
\text { passives } \\
\text { - Listen for who and what with } \\
\text { multiple nouns }\end{array}$ & $\begin{array}{l}\text { - Lecturing } \\
\text { videos } \\
\text { - Online } \\
\text { TOEFL-like } \\
\text { listening } \\
\text { preparation } \\
\text { - } \text { Listening } \\
\text { practice test }\end{array}$ & - Discussion \\
\hline 2. & 2 & $\begin{array}{l}\text { (continued) } \\
\text { TOEFL listening part } 1 \text { - listening } \\
\text { to short talk(s) } \\
\text { Function } \\
\text { - } \quad \text { Listen for expressions of } \\
\quad \text { agreement } \\
\text { - } \quad \text { Listen for expression of }\end{array}$ & $\begin{array}{l}\text { - } \text { TOEFL-like } \\
\text { materials } \\
\text { from } \\
\text { websites }\end{array}$ & $\begin{array}{l}\text { - Feedback } \\
\text { - Discussion }\end{array}$ \\
\hline
\end{tabular}




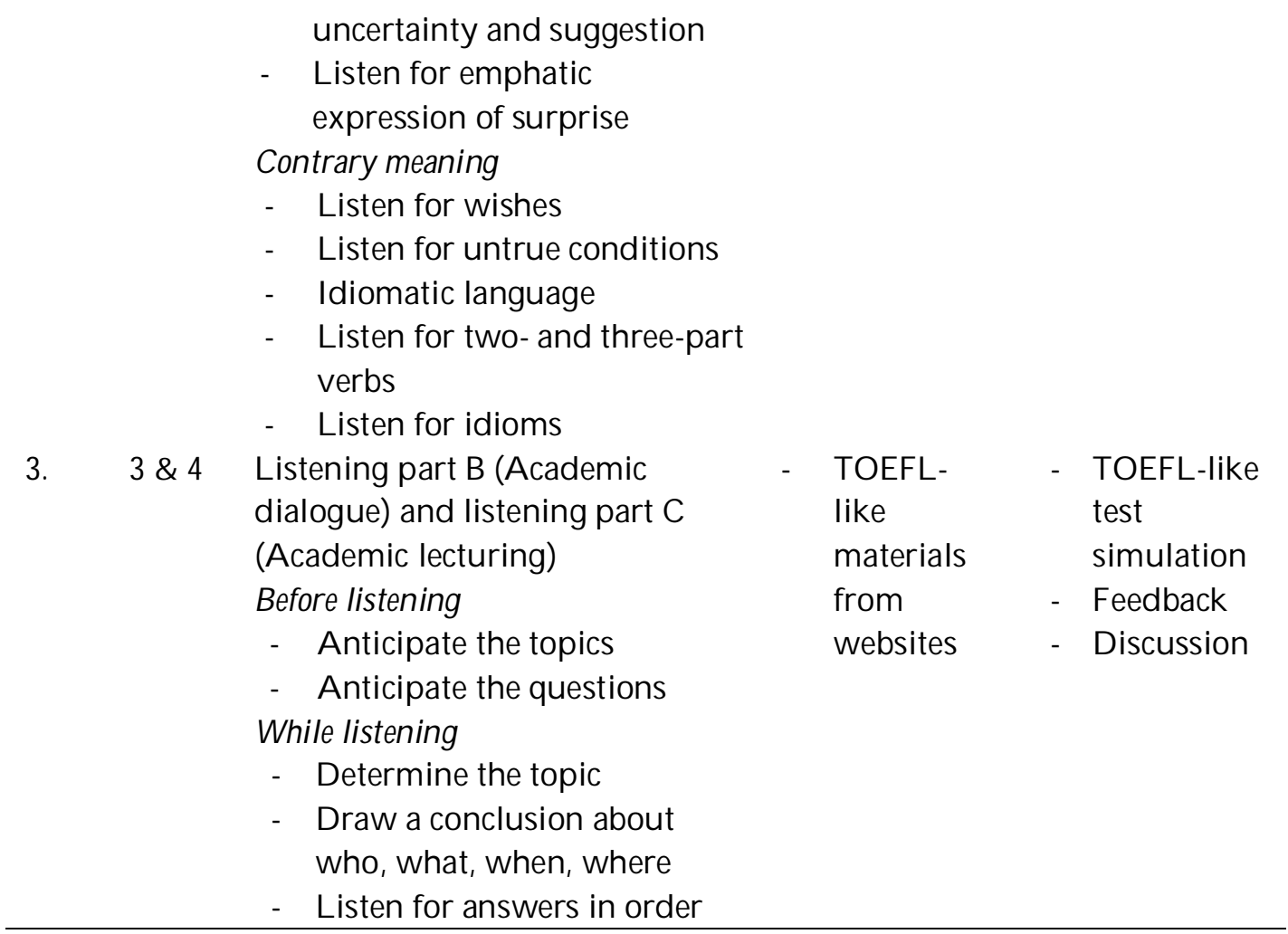

(Source: Phillips, 2003)

\section{Data analysis}

The quantitative data in this research was processed by using the IBM SPSS statistics 23 program. In order to design the tests (both pre-test and post-test), the researcher adopted the reliable TOEFL-like test using Longman Book. This test is chosen because it has been used worldwide for its high degree of accuracy and validity. The test items in this book have also been validated by the Language Center (Lembaga Bahasa) of the University of Muhammadiyah Malang. The Kolmogorov-Smirnov test was used to analyze the normality of data distribution. Further, based on the result of the Kolmogorov-Smirnov test, the researcher decided to use Wilcoxon Signed Ranks Test to analyze the significant value for the implementation of the flipped classroom to EFL students' listening comprehension because the result of the KolmogorovSmirnov test was not shown normally distributed (Oyeka \& Ebuh, 2012). Meanwhile, in terms of qualitative data, the results of the open-ended questions from this study were analyzed using N-Vivo 12 plus software, which was developed from many previous studies (Brandão, 2015; Escobar et al., 2019). All results obtained are coded using thematic coding consisting of autonomy, motivation, usefulness, engagement and satisfaction (Wang et al., 2019). As for 
validating the result, the researcher submitted the themes for verification to qualified qualitative analysts, followed by reviewing the analysis to see any differences. These steps of validation follow the application of Colaizzi's method (Sanders, 2003).

\section{Findings}

The impact of the flipped classroom on EFL students' listening comprehension skill

After having the treatment (a four-week intensive flipped classroom), the result of the student's post-test increased, compared to the result of the pre-test. It means that the students were able to improve their listening skills, especially in listening TOEFL-like test, as they got more practice for the pre-class activities. Even though the in-class time was so limited, they had more time to learn before class.

Table 2. The description of respondents and test of normality (Using KolmogorovSmirnov)

\begin{tabular}{llllll}
\hline & $\mathrm{N}$ & \multicolumn{2}{c}{ Sex } & \multicolumn{3}{l}{ Pre-test } & Post-test \\
\cline { 2 - 4 } & & Male & Female & \\
\hline Flipped classroom & 51 & 16 & 35 & 64.06 (mean) & 72.27 (mean) \\
Kolmogorov-Smirnov & & & & 0.000 & 0.535 \\
\hline
\end{tabular}

Table 2 shows that the number of respondents who had taken part in the flipped classroom was $(\mathrm{N}=51)$ with details of 16 men and 35 women. The mean pre-test value is 64.06 , while the mean post-test value is 72.27 . From the data normality tests, both on the pre-test and post-test scores using the KolmogorovSmirnov test, the results show that the pre-test value is $0.000 \varangle 0.05$, which means that the data is not normally distributed. Meanwhile, the post-test value is $0.535>0.05$ which means that the data is normally distributed. The existence of abnormal distribution of data makes the subsequent analysis must use a nonparametric test.

Table 3. The result of Wilcoxon Signed Ranks test

\begin{tabular}{llll}
\hline $\mathrm{N}$ & $\mathrm{p}$ & Probability of error & Result \\
\hline 51 & 0.000 & $5 \%(0.05)$ & Significant \\
\hline
\end{tabular}

Based on the results of non-parametric tests using the Wilcoxon Signed Ranks test in Table 3, it was found that a significant value (p) of $0.000 \varangle 0.05$.

Journal on English as a Foreign Language, 11(1), 21-41

p-ISSN 2088-1657; e-ISSN 2502-6615 
These results indicate a significant difference in learning outcomes when using flipped classroom in the learning process, referring to the result of the pre-test and post-test scores. This means that the use of flipped classroom is considered to significantly improve student learning outcomes and listening comprehension skills for TOEFL.

Table 4. The result of Mann-Whitney test

\begin{tabular}{lllll}
\hline & $\mathrm{N}$ & $\mathrm{p}$ & Probability of error & Result \\
\hline Pre-test & 51 & 0.292 & $5 \%(0.05)$ & Not significant \\
Post-test & 51 & 0.535 & $5 \%(0.05)$ & Not significant \\
\hline
\end{tabular}

To give additional information from the Mann-Whitney test result in Table 4, the given treatment during the flipped classroom is not influenced by gender. Other test results using the Mann-Whitney test to see differences in the effectiveness of flipped classroom use between men and women found that a significant value (p) $0.535>0.05$ on the post-test results. These results indicate that there is no difference in post-test scores by gender. This means that the effectiveness of using flipped classroom in the listening learning process does not differ significantly between men and women, or in other words, it is not gendered biased.

After all, the listening skills of EFL students, particularly for TOEFL testing by introducing flipped classroom improved after several weeks of treatment, including pre-class and in-class activities were provided. Moreover, the results of non-parametric tests using the Wilcoxon signed ranks test found a significant value $(\mathrm{p})$ of $0.000 \varangle 0.05$. Therefore, teaching listening using flipped classroom approach influenced EFL students' listening competence, and it was considered to be an effective treatment in enhancing the students' understating of the strategy and technique to answer TOEFL testing and how to improve their listening competence.

\section{The students' perceptions of their experience for having a flipped classroom}

With regards to the second research question about the perception of EFL students, the results showed that basically the students felt some benefits of having flipped classroom to improve their listening skills. Some of them expressed their satisfaction and the use of the flipped approach for their learning. Further, the students also felt that they became more motivated and more convenient to have their own learning phase (autonomous learning). Yet, some of them also confirmed some technical issues regarding the application used and the internet access.

Journal on English as a Foreign Language, 11(1), 21-41

p-ISSN 2088-1657; e-ISSN 2502-6615 
Table 5. Key characteristics of students' perceptions toward their experience in flipped

\begin{tabular}{lll} 
classroom & & \\
\hline Code categories & Indicators & Frequency \\
\hline \multirow{4}{*}{ Autonomous } & I can access it where ever and whenever & 14 \\
& Every time and everywhere & 23 \\
& I can access it outside the class & 5 \\
& Independent learning & 18 \\
Motivation & Flexible & 8 \\
& Own place and time & 4 \\
& It makes me to learn more & 3 \\
Usefulness & Want to learn about the materials again & 1 \\
& I can understand more & 11 \\
& Better understanding & 15 \\
Satisfaction & More practices & 13 \\
& I know more about the strategies & 2 \\
Drawbacks & Comfortable & 11 \\
& Effective & 32 \\
& Technical problems & 14 \\
\hline
\end{tabular}

Table 5 discusses the result of an open-ended questionnaire that has been coded into five categories using N-Vivo, including autonomous, motivation, usefulness, satisfaction, and drawbacks. A more detailed explanation is provided as follows.

\section{Autonomous}

During the flipped classroom implementation, students are required to study the content themselves outside the classroom as they take responsibility for their own learning. They are prompted to be autonomous (independent) learners since the content is provided by technology. Their learning takes place at their own pace, such as in their homes, in an individualized environment. The result of the open-ended questionnaire showed as follows:

I can access TOEFL at home so that independent learning can be more easily done. (Student\#15)

It's easy to access anytime and everywhere, so I can learn it and repeat it whenever I want. (Student\#8) 
The benefits, it can help us easier, and it's flexible. We could do the task everywhere as long as the place supports us to do the assignment. (Student\#12)

I think by using google classroom, the students do not have to go to the language laboratory to practice doing the TOEFL test, and it is quite convenient to be able to do TOEFL practice at the student's own place. (Student\#3)

\section{Motivation}

Students are provided with varied teaching media such as video, materials from websites and online quizzes. Those materials particularly trigger the students to study more about the materials before class. Some students declare that they are motivated to look back at the materials and watch the video before starting the class:

It makes me want to learn more and more understanding about the steps and strategies in answering questions, especially for TOEFL, by watching the video given. (Student\#2)

We can easier [easily] access it every time also everywhere, so in every change, if we have free time before starting the class and want to learn about the materials again (TOEFL, listening session I mean), we just easily open that google classroom without any limit. (Student\#30)

\section{Usefulness}

The majority of the students claimed that flipped classroom is very useful to help them to understand the given materials. Moreover, they can be more organized and structured to do their tasks. Regarding the usefulness, they mostly express positively:

I can understand more about the listening topic, and I can doublecheck my answer carefully before submitting it. (Student\#42)

The most useful thing is I can repeat the recording, so I can better understand what the speaker means. Finally, I find it easier to work on the questions. (Student\#33) 
It makes me more concentration [concentrated] to do all the tasks and more organized if there are [some] assignments. [I can] Know more about the steps and strategies in answering questions, especially for TOEFL. (Student\#13)

\section{Satisfaction}

In relation to the students' satisfaction, most of the students agreed that they felt comfortable and enjoyed both pre-class and in-class activities. As a result, they confirmed that flipped classroom is an effective way for their listening class:

It is simpler and more comfortable for homework and online class. So, when I join the meeting in class, I can share my work with others and learn together. (Student\#43)

Actually, when I use google classroom for the listening course, it is quite pretty good, simple, and easy to open up the file. The instruction given is also understandable. I do not need to go to the laboratory very often. (Student\#50)

I feel satisfied because using google classroom. We can learn more effectively cause [because] we have private listening material. During the class, I can share my problems that I found before. (Student\#29)

\section{Drawbacks}

However, most of the students complained about the technical issues in using google classroom. Some of the students expressed that flipped learning demanded a larger amount of internet connection, and it was sometimes burdening them. Here are some representative excerpts from open-ended questions:

Google classroom or every online classroom platform is mostly dependent on internet and WIFI, so in some cases, it will be troublesome if the students are in a place where there is no internet. (Student\#32)

The only drawbacks [is] just the Wi-Fi signal. Just it. (Student\#17) 
Sometimes the file of audio couldn't be played by google, so I need to download and arrange it first before work on the task. (Student\#27)

Sometimes audio in google classroom is a bit problematic and makes us confused. (Student\#6)

\section{Discussion}

\section{The impact of the flipped classroom on EFL students' listening comprehension skill}

With regard to the first research question, examining whether flipped classroom approach contributes to the students' listening comprehension, especially for TOEFL listening session, the result revealed that the average scores of the post-test (Mean $=72.27$ ) was higher than the average scores of pretest (Mean $=64.06$ ), emphasizing that students performed considerably better on the post-test after having flipped classroom. Related to the evidence on the improvement of students' listening competence, the result of the present study is compatible with a plethora of previous studies (Ahmad, 2016; Alhamami \& Khan, 2019; Astri et al., 2019; Khonamri et al., 2020; Roth \& Suppasetseree, 2016; Wang, 2017). Yet, this study is slightly different from those previous studies since the listening competence focused on specific listening proficiency, TOEFL listening section.

The students are offered to learn plenty of online learning resources from websites, watch video lecturing created by the teacher and video from YouTube related to the materials, and practice some online quizzes posted on google classroom. This facilitates students to access the language input as much as possible in their most convenient time. As it is supported by Yeşilçınar (2019), unlike the traditional classroom, the in-class time is devoted to practice in flipped learning, which maximizes the exposure to comprehensive input and interaction.

In this study, flipped classroom helps learners access pre-class input and use the whole class time to improve their listening skills and understanding toward the TOEFL listening section's strategy. For example, the students have to listen attentively to the given videos, gaining basic content about the material that allows them to participate effectively in the whole-class discussion. Similar to the previous study conducted by Lee and Wallace (2018), the students are triggered to learn independently by doing tasks and activities before class.

Journal on English as a Foreign Language, 11(1), 21-41

p-ISSN 2088-1657; e-ISSN 2502-6615 
Further, the students are more encouraged to ask any questions either face-toface or online. During in-class activities, students are required to work cooperatively. Accordingly, they improve their listening comprehension as they learn together and share their knowledge with others to find ways to solve their encountered problems.

\section{The students' perceptions of their experience for having a flipped classroom}

Furthermore, flipping classroom results not only enhances students' listening comprehension but also creates a positive perspective in their attitudes towards flipped classroom experience. The result of this study is in line with the previous studies regarding autonomous learning and flipped classroom (Andujar et al., 2020; Köroğlu \& Çakır, 2017; Mehring, 2010; Tsai, 2019). From those studies, flipped classroom generally helps learners take their role as independent learners, being highly responsible for their own learning. As demonstrated in this study's outcome, most students feel autonomy, which is correlated with higher self-regulation. Self-regulated learning focuses on how individuals orient their behaviors, cognitions, and affection to achieve the desired achievement goal. Self-regulated learners initiate and direct their learning activities and are thus active participants in their own learning processes (Silva et al., 2018; Marca et al., 2017). Since many students perform high self-regulation, they also report that they make some efforts to independently master material outside the classroom to develop their listening skills and be prepared to participate effectively in the classroom. Flipped classroom helps the students to learn the materials easily everywhere and anywhere. Further, they can practice several exercises to sharpen their listening skill in their most convenient time and place.

Additionally, high self-regulation is closely related to their motivation. Students are intrinsically motivated to learn the materials before class. Further, they also feel that various teaching multimedia such as video is interesting media. Since intrinsic motivation in learning is driven by individual interest or enjoyment in the task itself and does not rely on any external pressure, it can be assumed that flipped classroom effectiveness heavily depends on the student's self-motivation (Du et al., 2014). Consequently, students who are motivated will like to do the instructions for individual pre-class activities such as watching videos and having online quizzes and vice versa.

Concerning usefulness and satisfaction, the students express that flipped classroom is very useful for it is easy to access the materials they need to study more as it is similar to the finding from Awidi and Paynter (2019). Most of the

Journal on English as a Foreign Language, 11(1), 21-41

p-ISSN 2088-1657; e-ISSN 2502-6615 
students believe that flipped classrooms are very useful for understanding the materials, especially for some topics and specific strategies in doing TOEFL listening tests at their convenience. Moreover, they can be more organized and structured to do their tasks. Some students express their satisfaction since they are comfortable with both pre-class activities and in-class activities. They express their satisfaction since they have individual listening materials. Other students also expressed satisfaction regarding the clarity of the given instructions. Similarly, the discussions within the in-class sessions are useful for some other students. The claim made by these students are also supported by Zhonggen et al. (2019), affirming that students with a mobile learning platform are substantially more satisfied in EFL classes than those without it because this flipped platform is embedded with audio and video recourse that provide ample and interesting visual and listening inputs.

Although many students express their positive feedback toward their experience, almost all of the students declare technical issues that contribute to their dissatisfaction. One disadvantage of the flipped classroom is the fluctuation of Internet accessibility. Furthermore, students in poor areas may not have the resources to own the flipped classroom's Internet. Andujar et al. (2020), Ansori and Nurun (2018), Du et al. (2014), Mccarthy (2016), and Nawi et al. (2015) point out the same idea that the prominent technical issue in the implementation of the flipped classroom, whether in rural or urban areas, is the accessibility of the lesson outside the classroom which depends on internet access. Therefore, it is unsurprising that internet connection is the most technical problem the students complain about to their learning experience in this flipped approach. Alhamami and Khan (2019) add that poor internet connectivity could be a factor that discourages students from accessing the online lesson. Further, students report that the audio uploaded online is not compatible with their devices, and they have to download and play it using other applications. As a consequence, students feel less convenient learning through the flipped approach.

\section{Conclusion}

This present study concludes that the flipped classroom method in EFL listening classrooms promotes an effective approach to enhancing the students' listening skills, especially for TOEFL-like listening test. Most students showed a positive attitude toward their learning experience, such as having more autonomous (independent) to practice, feeling more motivated to learn, adjusting some comfortable and effective learning materials, and being satisfied

Journal on English as a Foreign Language, 11(1), 21-41

p-ISSN 2088-1657; e-ISSN 2502-6615 
with the learning process. Yet, several technical problems could not be avoided during the implementation of the flipped classroom. Some limitations, however, were included in this present research. The number of participants in this study was relatively small, and participants in the control group were not available. While this study's results provide some insights into the area of study, this research did not discuss other variables that influenced the students' learning process, such as motivation and learning strategies. Those aspects are suggested for further research. In addition, a similar study with different groups of learners, contexts, and language learning skills is highly required to provide a wider perspective on the implementation of the flipped classroom in EFL scopes.

\section{Acknowledgements}

The author would like to express her appreciation to her students of the Critical Listening course, English Language Education Department, Faculty of Teacher Training and Education, Universitas Muhammadiyah Malang, Indonesia. She thanks to her colleagues for the constructive feedback.

\section{ORCID}

Khoiriyah https: //orcid.org/0000-0001-5638-6633

\section{References}

Ahmad, S. Z. (2016). The flipped classroom model to develop Egyptian EFL students' listening comprehension. English Language Teaching, 9(9), 166178. https://doi.org/10.5539/elt.v9n9p166

Alhamami, M., \& Khan, M. R. (2019). Effectiveness of flipped language learning classrooms and students' perspectives. Journal on English as a Foreign Language, 9(1), 71-86. https://doi.org/10.23971/jefl.v9i1.1046

Alnuhayt, S. S. (2018). Investigating the use of the flipped classroom method in an EFL vocabulary course. Journal of Language Teaching and Research, 9(2), 236-242. https://doi.org/10.17507/jltr.0902.03

Andujar, A., Salaberri-Ramiro, M. S., \& Martínez, M. S. C. (2020). Integrating flipped foreign language learning through mobile devices: technology acceptance and flipped learning experience. Sustainability, 12(3), 1-12. https://doi.org/10.3390/su12031110

Ansori, M., \& Nurun, N. N. (2018). English teachers' perceived benefits and challenges of flipped classroom implementation. Journal of English Education and Linguistics Studies, 5(2), 211-227. 
https://doi.org/10.30762 /jeels.v5i2.820

Astri, U. S., Syarif, H., \& Ningsih, K. (2019). The effect of flipped classroom strategy on listening comprehension of undergraduate students at English Department in IAIN Batusangkar. Advances in Social Science, Education and Humanities Research, 335, 316-321. https://doi.org/10.2991/1cesshum-19.2019.51

Awidi, I. T., \& Paynter, M. (2019). The impact of a flipped classroom approach on student learning experience. Computers and Education, 128, 269-283. https://doi.org/10.1016/j.compedu.2018.09.013

Bezzazi, R. (2019). The effect of flipped learning on EFL learners' public speaking in Taiwan. Journal on English as a Foreign Language, 9(1), 1-19. http://dx.doi.org/10.23971/jefl.v9i1.1035

Brandão, C. (2015). Qualitative data analysis with NVivo. Qualitative Research in Psychology, 12(4), 492-294. https://doi.org/10.1080/14780887.2014.992750

Creswell, J. W. (2012). Educational research: planning, conducting and evaluating quantitative and qualitative research ( $4^{\text {th }}$ ed.). Boston: Pearson.

Du, S., Fu, Z., \& Wang, Y. (2014). The flipped classroom - advantages and challenges. International Conference on Economic Management and Trade Cooperation, 17-20.

El-Sawy, H. E. A. (2018). Flipping EFL university classes with blackboard system. English Language Teaching, 11(2), 31-43. https://doi.org/10.5539/elt.v11n2p31

Emerick, M. R. (2018). Explicit teaching and authenticity in L2 listening instruction: University language teachers' beliefs. System, 80, 1-13. https://doi.org/10.1016/.system.2018.11.004

Escobar, F., Munoz, L., \& Velandia, A. (2019). Motivation and e-learning English as a foreign language: a qualitative study. Heliyon, 5, 1-7. https://doi.org/10.1016/h.heliyon.2019.e02394

Fauzan, A., \& Ngabut, M. N. (2018). EFL students' perception on flipped learning in writing class. Journal on English as a Foreign Language, 8(2), 115-129. https://doi.org/10.23971 ðefl.v8i2.792

Golonka, E. M., Bowles, A. R., Frank, V. M., Richardson, D. L., \& Freynik, S. (2014). Technologies for foreign language learning: a review of technology types and their effectiveness. Computer Assisted Language Learning, 27(1), 70-105. https://doi.org/10.1080/09588221.2012.700315

Haghighi, H., Jafarigohar, M., Khoshsima, H., \& Vahdany, F. (2019). Impact of flipped classroom on EFL learners' appropriate use of refusal: achievement, participation, perception. Computer Assisted Language Learning, 32(3), 261-293. https://doi.org/10.1080/09588221.2018.1504083 
Hamouda, A. (2013). An investigation of listening comprehension problems encountered by Saudi students in the EFL listening classroom. International Journal of Academic Research in Progressive Education and Development, 2(2), 113-155.

Karabulut-Ilgu, A., Yao, S., Savolainen, P., \& Jahren, C. (2018). Student perspectives on the flipped-classroom approach and collaborative problem-solving process. Journal of Educational Computing Research, 56(4), 513-537. https://doi.org/10.1177/0735633117715033

Kazemian, M., Khonamri, F., Azizi, M., \& Molana, K. (2019). Dynamic assessment in developing EFL learners' depth of vocabulary knowledge through critical reading. Jurnal Pendidikan Malaysia, 44(2), 20-29. https://doi.org/10.17576/JPEN-2019-44.02-03

Khonamri, F., Azizi, M., \& Klarik, R. (2020). Using interactive e-based flipped learning to enhance EFL literature students' critical reading. Science for Education Today, 10(1), 30-42. https://doi.org/10.15293/2658

Kim, J. E., Park, H., Jang, M., \& Nam, H. (2017). Exploring flipped classroom effects on second language learners' cognitive processing. Foreign Language Annals, 50(2), 260-284. https://doi.org/10.1111/flan.12260

Kırmızıa, Ö., \& Kömeçb, F. (2019). The impact of the flipped classroom on receptive and productive vocabulary learning. Journal of Language and Linguistic Studies, 15(2), 437-449. https://doi.org/7263/jlls.586096

Köroğlu, Z. Ç., \& Çakır, A. (2017). Implementation of flipped instruction in language classrooms: an alternative way to develop speaking skills of pre-service English language teachers. International Journal of Education and Development, 13(2) , 42-55.

Lee, G., \& Wallace, A. (2018). Flipped learning in the English as a foreign language classroom: outcomes and perceptions. TESOL Quarterly, 52(1), 62-84. https://doi.org/10.1002/tesq.372

Leis, A., \& Brown, K. (2018). Flipped learning in an EFL environment: does the teacher's experience affect learning outcomes? The EuroCALL Review, 26(1), 3. https://doi.org/10.4995/eurocall.2018.8597

Lo, C. K., \& Hew, K. F. (2017). A critical review of flipped classroom challenges in K-12 education: possible solutions and recommendations for future research. Research and Practice in Technology Enhanced Learning, 12(1), 1-12. https://doi.org/10.1186/s41039-016-0044-2

Love, B., Hodge, A., Grandgenett, N., \& Swift, A. W. (2014). Student learning and perceptions in a flipped linear algebra course. International Journal of Mathematical Education in Science and Technology, 45(3), 317-324. https://doi.org/10.1080/0020739X.2013.822582 
Marca, A. La, \& Longo, L. (2017). Addressing student motivation, selfregulation, and engagement in flipped classroom to decrease boredom. International Journal of Information and Education Technology, 7(3), 230-235. https://doi.org/10.18178/jijiet.2017.7.3.871

Maxson, K., \& Szaniszlo, Z. (2015). An introduction to the flipped classroom. Primus, 25(8), 597-599. https://doi.org/10.1080/10511970.2015.1058307

Mccarthy, J. (2016). Reflections on a flipped classroom in first year higher education. Issues in Educational Research, 26(2), 332-350.

Mehring, J. G. (2010). An exploratory study of the lived experiences of Japanese undergraduate EFL students in the flipped classroom. The International Research Foundation for English Language Education, 11, 1-5.

Oyeka, I. C. A., \& Ebuh, G. U. (2012). Modified Wilcoxon Signed-Rank test. Open Journal of Statistics, 2, 172-176. https://doi.org/10.4236/ojs.2012.22019

Phillips, D. (2003). Longman complete course for the TOEFL test. New York: Longman.

Privitera, G. J., \& Delzell, L. A. (2019). Quasy-experimental and single-case experimental designs. Research Methods for Education. California: SAGE Publications.

Rintaningrum, R. (2016). I find it easy to learn English when.........: lecturers' perspective. Jambi International Seminar on Education 1 (JISE) (pp. 14-21), Jambi: Jambi University Press.

Rintaningrum, R. (2018). Investigating reasons why listening in English is difficult: voice from foreign language learners. Asian EFL Journal, 20(11), 112-120. Retrieved from https:/fwww.asian-efl-journal.com

Rosell-Aguilar, F., Beaven, T., Fuertes Gutiérrez, M., \& Martínez-Carrasco, R. (2018). Social media in L2 education: exploring on-line collaborative writing in EFL settings. In F. Rosell-Aguilar, T. Beaven, \& M. Fuertes Gutiérrez (Eds), Innovative language teaching and learning at university: integrating informal learning into formal language education (pp. 17-26). Research-publishing.net. https://doi.org/10.14705/rpnet.2018.22.772

Roth, C., \& Suppasetseree, S. (2016). Flipped classroom: can it enhance English listening comprehension for pre-university students in Cambodia? Proceedings of Classic: Learning in and beyond the Classroom: Ubiquity in Foreign Language Education, 255-264.

Sanders, C. (2003). Application of Colaizzi's method: interpretation of an auditable decision trail by a novice researcher. Contemporary Nurse: A Journal for the Australian Nursing Profession, 14(3), 292-302. https://doi.org/10.5172/conu.14.3.292

Shih, H. chia J., \& Huang, S. hui C. (2019). College students' metacognitive

Journal on English as a Foreign Language, 11(1), 21-41

p-ISSN 2088-1657; e-ISSN 2502-6615 
strategy use in an EFL flipped classroom. Computer Assisted Language Learning, 27(1), 1-30. https://doi.org/10.1080/09588221.2019.1590420

Silva, J. C. S., Zambom, E., Rodrigues, R. L., Ramos, J. L. C., \& Da Fonseca De Souza, F. (2018). Effects of learning analytics on students' self-regulated learning in flipped classroom. International Journal of Information and Communication Technology Education, 14(3), 91-107. https://doi.org/10.4018/JICTE.2018070108

Su Ping, R. L., Verezub, E., Adi Badiozaman, I. F. bt, \& Chen, W. S. (2019). Tracing EFL students' flipped classroom journey in a writing class: lessons from Malaysia. Innovations in Education and Teaching International, 1-12. https://doi.org/10.1080/14703297.2019.1574597

Tecedor, M., \& Perez, A. (2019). Perspectives on flipped L2 classes: implications for learner training. Computer Assisted Language Learning, 1-22. https://doi.org/10.1080/09588221.2019.1626439

Tsai, Y. R. (2019). Promotion of learner autonomy within the framework of a flipped EFL instructional model: Perception and perspectives. Computer Assisted Language Learning, 1-32. https://doi.org/10.1080/09588221.2019.1650779

Turan, Z., \& Akdag-Cimen, B. (2019). Flipped classroom in English language teaching: a systematic review. Computer Assisted Language Learning, 1-17. https://doi.org/10.1080/09588221.2019.1584117

Vygotsky, L. S. (1978). Mind in society: the development of higher psychological processes. Cambridge, MA: Harvard University Press.

Wang, J. (2017). The application of flipped classroom in college English listening, viewing and speaking class. Advances in Social Science, Education and Humanities Research, 123, 1823-1826. https://doi.org/10.2991/icesame17.2017.386

Wang, N., Chen, J., Tai, M., \& Zhang, J. (2019). Blended learning for Chinese university EFL learners: learning environment and learner perceptions. Computer Assisted Language Learning, 1-27. https://doi.org/10.1080/09588221.2019.1607881

Yeşilçınar, S. (2019). Using the flipped classroom to enhance adult EFL learners' speaking skills. Pasaa, 58, 206-232.

Zhonggen, Y., Ying, Z., Zhichun, Y., \& Wentao, C. (2019). Student satisfaction, learning outcomes, and cognitive loads with a mobile learning platform. Computer Assisted Language Learning, 32(4), 323-341. https://doi.org/10.1080/09588221.2018.1517093 